\title{
AN INVESTIGATION OF MOTIVATIONAL STRATEGIES USED BY ENGLISH TEACHERS IN TEACHING EFL IN SECONDARY ISLAMIC SCHOOLS IN TANGERANG
}

\author{
Fidaniar Tiarsiwi, Dini Amaniah \\ University of Muhammadiyah Prof. Dr. HAMKA \\ shewe87@uhamka.ac.id; dini.amaniah29@gmail.com
}

\begin{abstract}
The study aims to investigate the motivational strategies used by English teachers in teaching EFL in secondary Islamic schools in Tangerang and analysed it based on four motivational aspects as proposed by Zoltan Dornyei (2001). The focus question of the study was the way of motivational strategies used by English teachers in teaching EFL in secondary Islamic schools in Tangerang. The sub-focus questions of the study were the frequency of motivational strategies used by English teachers in teaching EFL in secondary Islamic schools in Tangerang and the implementation of motivational strategies that the English teachers used in teaching EFL in secondary Islamic schools in Tangerang. To answer the questions, the study employed a qualitative approach that applied a case study design through questionnaire, semi-structured interview and observation to collect the data. The participants of this study were twenty-five English teachers. Six English teachers were selected for individual interviews and classroom observations based on the resulted of the questionnaire which had been filled in by twenty-five English teachers. Those six interviewees were selected according to the result of the questionnaire. Two were from good category, other two interviewees were selected as the moderate, while the other two were from poor category.
\end{abstract}

Keywords: motivation, motivational strategies, teaching strategy

\section{INTRODUCTION}

Motivation is one of crucial things that lead students in achieving their goals. Maeng \& Lee (2015) state motivation is one of the important factors in the success of learning English as foreign language. English teachers often say that motivation influences the success of learners (Dornyei, 2001). It means that how successful the students depend on how motivated they are. Therefore, without motivation, success will be hard to come by in the learning process. Individuals who have high motivation are more likely to improve organizational processes and performance compared to those who have a low motivation (Sucuoglu, 2017). In brief, motivation can probably be one of the essential aspects to help the students' learning. In fact, many students in schools feel demotivated toward learning English. Dornyei, Zoltan \& Ushioda, Ema (2011) state that demotivated learner is someone who was once motivated but has lost his or her interest for some reasons. It means that demotivating relate to negative aspects of the institutionalized learning context.

In general, Indonesian students tend to be passive and nonverbal in class. They rarely initiate class discussion until they are called on. This is because of the nature of the course content, teaching method assessment (Bradford, 2007). They feel reluctant to be active in English classroom (Park, 2000). Added by Kassing (2011) mentions that some EFL teachers are not aware that their motivational strategies have impact on students' motivation. Another 
problem that might cause their motivation change in learning the language is a fact that English is a foreign language not a second language in Indonesia (Liando, Moni \& Baldauf, 2005). The students do not have life experiences using English and they are not expected to be able to speak English. The students use Lingua Franca, Bahasa Indonesia mostly at school and sometimes at home. Hence, the frequency that students have in exploring the target language also becomes one of reasons why students have problems in learning English. According to (Sugita \& Takeuchi, n.d.) students always face many problems when they learn English as foreign language because students do not have many opportunities to use English in their daily lives. They learn English in the classroom and usually have little chance to speak English outside classroom. It means that it is extremely challenging to teachers to motivate their students to learn English more enjoyably.

Teacher's role in motivating the students is important, and the study of teacher of motivational strategies was held to get more explanation of motivational strategies (Alshehri, 2013). Dornyei (2001) states motivational strategies as techniques that promote the individual's goal-related behavior. He also states that motivational strategies refer to the effect of motivation that is consciously given to achieve a number of systematic and longlasting positive effects. The effective teaching various motivational strategies in learning foreign languages for enhancing student motivation, has become an important part that teachers use in English as foreign language classroom (Sucuoglu, 2017). From that statement, it is clear that teachers, especially language teachers, should have ability to make positive strategies and good relation with students in the classroom. If all of classroom strategies can support each other, it will build students motivation to learn confidently. Moskovsky et al (2013) mention that teachers' motivational strategies might enhance motivation in learning English. Moreover, Wilson-daily \& Gardner (2009) suggest that teacher motivation is related to teacher use of motivational strategies, which in turn are related to students' motivation and English achievement. From the statement above, that means giving them motivational strategies for learning to be one of the big steps that teachers can use to achieve success in learning L2.

In line to how important teaching motivational strategies is, teachers ideally must know how to apply encouraging students' motivation. Unfortunately not all or only few teachers realize how important it is. Added by Kassing (2011) mentions that some EFL teachers are not aware that their motivational strategies have impact on students' motivation. Similar fact happened as well at one of Islamic Schools in Tangerang. The researcher's brother, student of Islamic school in Tangerang, shared his experiences that he did not like English because his teachers did not motivate him to like English. He claimed that most of students were not interested in learning English. This reality was a bit questioning as most of Islamic schools were popular nowadays in some regions in Tangerang. Many parents preferred to register their children to the Islamic Schools. It was not only because the children want to be educated Islamically, but also Islamic schools were considered to have good qualification in other aspects including the subjects taught. It also supported Vitasari (2017) states that parents' motivation entered their children in Islamic schools because Islamic schools really help parents in educating their children. For this reason, they need a place or school that can provide wider knowledge to their children. From the problem above, the researcher was inspired to find out how often English teachers use motivational strategies in teaching EFL and how to apply motivational strategies in teaching EFL in secondary Islamic schools in Tangerang. 


\section{METHOD}

The study used case study design that is instrumental case study through questionnaire, interview and classroom observation to collect data. The results were defined based on the motivational strategies mentioned by teachers, that is, how often teachers used motivational strategies and how they apply them. In finding an in-depth exploration of the motivational strategies, the researcher used the components of motivational teaching strategies in the L2 classroom (Dornyei, 2001, p.29) as the underlying theory of this research. To collect the data, the teachers, as participants were given a questionnaire to rate outside class time. The questionnaire motivational strategies framework adapted by of Dornyei (2001). It took approximately 25-30 minutes for most teachers to complete the questionnaire. Teacher Questionnaire consisted of two parts: profile questions and teaching strategy rating section, which asked teachers about their age, gender, teaching experience and degrees obtained. The questionnaire consists of four components motivational strategies. They are creating basic motivational conditions, generating initial motivation, maintaining and protecting motivation and encouraging positive self-evaluation. The strategies used in the Likert-scale part of the questionnaire were adapted from Dörnyei's (2001a) motivational strategy framework. Twenty-five English teachers consented and rated the 20 motivational teaching strategies on a Likert-scale from 1 to 5, consisting of four components of Dörnyei's Motivational Teaching Model. On the Likert-scale, 1 stood for 'Never' while 5 for 'Always'. Furthemore, the writer used semi-structures interviews to collect the data. According to Karatas et al (2016) the interview is chosen as it develops in-depth information of phenomenon. The interview was conducted to face to face interview. The last classroom observation was a data gathering technique where the researcher directly documents activities inside the classroom by watching, listening, and recording (Nunan \& Bailey, 2009). Classroom observation enabled the researcher to understand the participants' behavior within the research setting. The current study used questionnaire, semi structured interview and classroom observation to collect data. The researcher used a formula for the questionnaire. The researcher analysed motivational strategies used by English teachers uses qualitative survey research to identify and find out how often English teachers used motivational strategies.

The formula for counting this analysis is

$$
\begin{aligned}
& \mathrm{P}=\mathrm{F} / \mathrm{N} \times 100 \% \\
& \mathrm{P}=\text { percentage } \\
& \mathrm{F}=\text { frequency } \\
& \mathrm{N}=\text { number of sample }
\end{aligned}
$$

Next, for the semi structured interview and classroom observation the data analysis is steps taken after collecting data through the semi-structured interviews with teachers. There were some steps in analyzing the data. Data were evaluated as they were collected through the process of coding. The first step was transcribing the data in the audio form to the written form. It was to make it easier for the researcher to analyze the data. The researcher collated the data from each case with Dörnyei's MTP framework. The data from each teacher (semistructured interviews transcriptions, observation notes) was coded. A code was an idea identified by the teachers as being important. These codes were then sorted into patterns these were determined by the responses of the teachers in relation to the different behaviors/tasks they were undertaking in the classroom. The patterns were then sorted into 
themes and this was achieved by linking similar patterns together that encapsulated an overall theme. The researcher merged the data from each teacher and considered them within the case. Then, the researcher identified and translated indicative quotes to support the themes from teachers' data. The themes that emerged from each case were analyzed using Dornyei's framework.

\section{FINDINGS AND DISCUSSION}

The questionnaire, semi structured-interviews and classroom observation revealed some answers of the focus and sub focus questions of the study. The focus question of the study is the way of motivational strategies used by English teachers in teaching EFL in secondary Islamic school in Tangerang. The sub-focus questions of the study are the frequency of motivational strategies used by English teachers in teaching EFL in secondary Islamic schools in Tangerang and the implementation of motivational strategies that English language teachers used in teaching EFL in secondary Islamic schools in Tangerang. The researcher found the responses, as follows:

Table 1: Descriptive Statistic about The Frequency of Motivational Strategies used by English Teachers in Teaching EFL in Secondary Islamic Schools in Tangerang.

\begin{tabular}{|c|c|c|c|c|c|c|}
\hline \multirow{2}{*}{\multicolumn{2}{|c|}{$\begin{array}{l}\text { 1. Creating Basic Motivational } \\
\text { Conditions }\end{array}$}} & \multicolumn{5}{|c|}{ Rating Scale } \\
\hline & & \multirow{2}{*}{$\begin{array}{c}\text { Always } \\
19 \\
(76 \%)\end{array}$} & \multirow{2}{*}{$\begin{array}{c}\text { Often } \\
6 \\
(24 \%)\end{array}$} & \multirow{2}{*}{$\begin{array}{c}\text { Sometimes } \\
0 \\
(0 \%)\end{array}$} & \multirow{2}{*}{$\begin{array}{c}\text { Rarely } \\
0 \\
(0 \%)\end{array}$} & \multirow{2}{*}{$\begin{array}{c}\text { Never } \\
0 \\
(0 \%)\end{array}$} \\
\hline 1 & $\begin{array}{l}\text { I show proper good } \\
\text { behaviour to the }\end{array}$ & & & & & \\
\hline 2 & $\begin{array}{l}\text { I develop personal } \\
\text { good relationship with } \\
\text { students }\end{array}$ & $\begin{array}{c}22 \\
(88 \%)\end{array}$ & $\begin{array}{c}3 \\
(12 \%)\end{array}$ & $\begin{array}{c}0 \\
(0 \%)\end{array}$ & $\begin{array}{c}0 \\
(0 \%)\end{array}$ & $\begin{array}{c}0 \\
(0 \%)\end{array}$ \\
\hline 3 & $\begin{array}{l}\text { I create a pleasant and } \\
\text { supportive atmosphere in } \\
\text { the classroom }\end{array}$ & $\begin{array}{c}17 \\
(68 \%)\end{array}$ & $\begin{array}{c}6 \\
(24 \%)\end{array}$ & $\begin{array}{c}2 \\
(8 \%)\end{array}$ & $\begin{array}{c}0 \\
(0 \%)\end{array}$ & $\begin{array}{c}0 \\
(0 \%)\end{array}$ \\
\hline 4 & $\begin{array}{l}\text { I create cohesive } \\
\text { learner group with } \\
\text { appropriate group } \\
\text { norms }\end{array}$ & $\begin{array}{c}16 \\
(64 \%)\end{array}$ & $\begin{array}{c}9 \\
(36 \%)\end{array}$ & $\begin{array}{c}0 \\
(0 \%)\end{array}$ & $\begin{array}{c}0 \\
(0 \%)\end{array}$ & $\begin{array}{c}0 \\
(0 \%)\end{array}$ \\
\hline \multirow{2}{*}{2.} & \multirow{2}{*}{ Generating Initial Motivation } & \multicolumn{5}{|c|}{ Rating Scale } \\
\hline & & Always & Often & Sometimes & Rarely & Never \\
\hline 5 & $\begin{array}{l}\text { I promote the students' } \\
\text { language-related } \\
\text { values }\end{array}$ & $\begin{array}{c}2 \\
(8 \%)\end{array}$ & $\begin{array}{c}5 \\
(20 \%)\end{array}$ & $\begin{array}{c}8 \\
(32 \%)\end{array}$ & $\begin{array}{c}10 \\
(40 \%)\end{array}$ & $\begin{array}{c}0 \\
(0 \%)\end{array}$ \\
\hline 6 & $\begin{array}{l}\text { I develop the students' } \\
\text { intrinsic interest in the L2 } \\
\text { learning process }\end{array}$ & $\begin{array}{c}10 \\
(40 \%)\end{array}$ & $\begin{array}{c}13 \\
(52 \%)\end{array}$ & $\begin{array}{c}2 \\
(8 \%)\end{array}$ & $\begin{array}{c}0 \\
(0 \%)\end{array}$ & $\begin{array}{c}0 \\
(0 \%)\end{array}$ \\
\hline
\end{tabular}




\begin{tabular}{|c|c|c|c|c|c|c|}
\hline 7 & $\begin{array}{l}\text { I promote 'integrative' } \\
\text { (external) values by } \\
\text { encouraging a positive } \\
\text { and open-minded } \\
\text { attitude towards the } \\
\text { language learning }\end{array}$ & $\begin{array}{c}6 \\
(24 \%)\end{array}$ & $\begin{array}{c}8 \\
(32 \%)\end{array}$ & $\begin{array}{c}11 \\
(44 \%)\end{array}$ & $\begin{array}{c}0 \\
(0 \%)\end{array}$ & $\begin{array}{c}0 \\
(0 \%)\end{array}$ \\
\hline 8 & $\begin{array}{l}\text { I promote students' } \\
\text { awareness of the } \\
\text { instrumental values (e.g. } \\
\text { accomplishing goals, invite } \\
\text { native speaker and } \\
\text { encourage students to use } \\
\text { English outside classroom) } \\
\text { associated with learning a } \\
\text { foreign language }\end{array}$ & $\begin{array}{c}9 \\
(36 \%)\end{array}$ & $\begin{array}{c}13 \\
(52 \%)\end{array}$ & $\begin{array}{c}2 \\
(8 \%)\end{array}$ & $\begin{array}{c}1 \\
(4 \%)\end{array}$ & $\begin{array}{c}0 \\
(0 \%)\end{array}$ \\
\hline 9 & $\begin{array}{l}\text { I increase students' } \\
\text { expectations of success in } \\
\text { learning }\end{array}$ & $\begin{array}{c}8 \\
(32 \%)\end{array}$ & $\begin{array}{c}15 \\
(60 \%)\end{array}$ & $\begin{array}{c}2 \\
(8 \%)\end{array}$ & $\begin{array}{c}0 \\
(0 \%)\end{array}$ & $\begin{array}{c}0 \\
(0 \%)\end{array}$ \\
\hline 10 & $\begin{array}{l}\text { I make the curriculum and } \\
\text { the teaching materials } \\
\text { relevant to the students }\end{array}$ & $\begin{array}{l}16 \\
(64 \%)\end{array}$ & $9(36 \%)$ & $0(0 \%)$ & $0(0 \%)$ & $0(0 \%)$ \\
\hline 11 & $\begin{array}{l}\text { I help students to create } \\
\text { realistic students' beliefs } \\
\text { and } \\
\text { goals }\end{array}$ & $\begin{array}{c}8 \\
(32 \%)\end{array}$ & $\begin{array}{c}6 \\
(24 \%)\end{array}$ & $\begin{array}{c}11 \\
(44 \%)\end{array}$ & $\begin{array}{c}0 \\
(0 \%)\end{array}$ & $\begin{array}{c}0 \\
(0 \%)\end{array}$ \\
\hline \multirow{2}{*}{\multicolumn{2}{|c|}{$\begin{array}{l}\text { 3. Maintaining and Protecting } \\
\text { Motivation }\end{array}$}} & \multicolumn{5}{|c|}{ Rating Scale } \\
\hline & & Always & Often & Sometimes & Rarely & Never \\
\hline 12 & $\begin{array}{l}\text { I make learning } \\
\text { stimulating and } \\
\text { enjoyable }\end{array}$ & $\begin{array}{c}14 \\
(56 \%)\end{array}$ & $\begin{array}{c}8 \\
(32 \%)\end{array}$ & $\begin{array}{c}3 \\
(12 \%)\end{array}$ & $\begin{array}{c}0 \\
(0 \%)\end{array}$ & $\begin{array}{c}0 \\
(0 \%)\end{array}$ \\
\hline 13 & $\begin{array}{l}\text { I present tasks in a } \\
\text { motivating way }\end{array}$ & $\begin{array}{c}15 \\
(60 \%\end{array}$ & $\begin{array}{c}7 \\
(28 \%)\end{array}$ & $\begin{array}{c}3 \\
(12 \%)\end{array}$ & $\begin{array}{c}0 \\
(0 \%)\end{array}$ & $\begin{array}{c}0 \\
(0 \%)\end{array}$ \\
\hline 14 & $\begin{array}{l}\text { I use goal-setting } \\
\text { methods in my } \\
\text { classroom }\end{array}$ & $\begin{array}{c}5 \\
(20 \%)\end{array}$ & $\begin{array}{c}12 \\
(48 \%)\end{array}$ & $\begin{array}{c}8 \\
(32 \%)\end{array}$ & $\begin{array}{c}0 \\
(0 \%)\end{array}$ & $\begin{array}{c}0 \\
(0 \%)\end{array}$ \\
\hline
\end{tabular}




\begin{tabular}{|c|c|c|c|c|c|c|}
\hline 15 & $\begin{array}{l}\text { I build students' } \\
\text { confidence by } \\
\text { providing regular } \\
\text { encouragement }\end{array}$ & $\begin{array}{c}14 \\
(56 \%)\end{array}$ & $\begin{array}{c}8 \\
(32 \%)\end{array}$ & $\begin{array}{c}3 \\
(12 \%)\end{array}$ & $\begin{array}{c}0 \\
(0 \%)\end{array}$ & $\begin{array}{c}0 \\
(0 \%)\end{array}$ \\
\hline 16 & $\begin{array}{l}\text { I increase student } \\
\text { motivation by } \\
\text { promoting learner } \\
\text { autonomy }\end{array}$ & $\begin{array}{c}0 \\
(0 \%)\end{array}$ & $\begin{array}{c}0 \\
(0 \%)\end{array}$ & $\begin{array}{c}7 \\
(28 \%)\end{array}$ & $\begin{array}{c}5 \\
(20 \%)\end{array}$ & $\begin{array}{c}13 \\
(52 \%)\end{array}$ \\
\hline 17 & $\begin{array}{l}\text { I increase the students' } \\
\text { self-motivating capacity }\end{array}$ & $\begin{array}{c}5 \\
(20 \%)\end{array}$ & $\begin{array}{c}7 \\
(28 \%)\end{array}$ & $\begin{array}{c}10 \\
(40 \%)\end{array}$ & $\begin{array}{c}3 \\
(12 \%)\end{array}$ & $\begin{array}{c}0 \\
(0 \%)\end{array}$ \\
\hline \multirow{2}{*}{\multicolumn{2}{|c|}{$\begin{array}{l}\text { 4. Encouraging Positive Self- } \\
\text { evaluation }\end{array}$}} & \multicolumn{5}{|c|}{ Rating Scale } \\
\hline & & Always & Often & Sometimes & Rarely & Never \\
\hline 18 & $\begin{array}{l}\text { I promote effort } \\
\text { among students }\end{array}$ & $\begin{array}{c}14 \\
(56 \%)\end{array}$ & $\begin{array}{c}8 \\
(32 \%)\end{array}$ & $\begin{array}{c}3 \\
(12 \%)\end{array}$ & $\begin{array}{c}0 \\
(0 \%)\end{array}$ & $\begin{array}{c}0 \\
(0 \%)\end{array}$ \\
\hline 19 & $\begin{array}{l}\text { I provide students } \\
\text { with positive feedback }\end{array}$ & $\begin{array}{c}18 \\
(72 \%)\end{array}$ & $\begin{array}{c}7 \\
(28 \%)\end{array}$ & $\begin{array}{c}0 \\
(0 \%)\end{array}$ & $\begin{array}{c}0 \\
(0 \%)\end{array}$ & $\begin{array}{c}0 \\
(0 \%)\end{array}$ \\
\hline 20 & $\begin{array}{l}\text { I offer reward in a } \\
\text { motivational manner and } \\
\text { using grades in a } \\
\text { motivating way }\end{array}$ & $\begin{array}{c}15 \\
(60 \%\end{array}$ & $\begin{array}{c}7 \\
(28 \%)\end{array}$ & $\begin{array}{c}3 \\
(12 \%)\end{array}$ & $\begin{array}{c}0 \\
(0 \%)\end{array}$ & $\begin{array}{c}0 \\
(0 \%)\end{array}$ \\
\hline
\end{tabular}

Table 2: A Profile of participants in the semi-structured interviews

\begin{tabular}{|c|c|l|}
\hline 1. & $\begin{array}{c}\text { Teacher } \\
1\end{array}$ & $\begin{array}{l}\text { Age: } 28 \\
\text { Last academic degree: Bachelor } \\
\text { Teaching Experiences: } 8 \text { years }\end{array}$ \\
\hline 2. & $\begin{array}{c}\text { Teacher } \\
2\end{array}$ & $\begin{array}{l}\text { Age: } 43 \\
\text { Last academic degree: Bachelor } \\
\text { Teaching Experiences: } 14 \text { years }\end{array}$ \\
\hline 3. & $\begin{array}{c}\text { Teacher } \\
3\end{array}$ & $\begin{array}{l}\text { Age: } 23 \\
\text { Last academic degree: Bachelor } \\
\text { Teaching Experiences: } 3 \text { years }\end{array}$ \\
\hline 4. & $\begin{array}{c}\text { Teacher } \\
4\end{array}$ & $\begin{array}{l}\text { Age: } 45 \\
\text { Last academic degree: Bachelor } \\
\text { Teaching Experiences: } 10 \text { years }\end{array}$ \\
\hline 5. & Teacher & $\begin{array}{l}\text { Age: } 24 \\
\text { Last academic degree: } \text { Bachelor } \\
\text { Teaching Experiences: } 2 \text { years }\end{array}$ \\
\hline
\end{tabular}




\begin{tabular}{|l|c|l|}
\hline 6. & $\begin{array}{c}\text { Teacher } \\
6\end{array}$ & $\begin{array}{l}\text { Age: } 31 \\
\text { Last academic degree: Bachelor } \\
\text { Teaching Experiences: 9 years }\end{array}$ \\
\hline
\end{tabular}

\section{The Frequency of Motivational Strategies used by English Teachers in Teaching English as a Foreign Language}

Regarding to the table below (table I), it can be shown that the frequency of motivational strategies used by English teachers in teaching English as Foreign Language in Secondary Islamic Schools in Tangerang is described from which "always" respond to "never" as follows:

There are $88 \%$ of teachers who responded they always developed personal good relationship with students, $76 \%$ showed proper good behaviour to the students, $72 \%$ provided students with positive feedback, 68\% created a pleasant and supportive atmosphere in the classroom and $64 \%$ made the curriculum and the teaching relevant to the students.

Next, there are $60 \%$ of teachers who responded they often increased students' expectations of success in learning, 52\% developed the students' intrinsic interest in the L2 learning process and promoted students' awareness of the instrumental values (e.g. accomplishing goals, invited native speaker and encouraged students to use English outside classroom) associated with learning a foreign language, $48 \%$ used goal-setting methods in my classroom.

Furthermore, there are $44 \%$ of teachers who responded they sometimes promoted 'integrative' (external) values by encouraging a positive and open-minded attitude towards the language learning and helped students to create realistic students' beliefs and goals, $40 \%$ increased the students' self-motivating capacity. Meanwhile, there was $40 \%$ of teachers who responded they rarely promoted the students' language-related values. The last category, there is $52 \%$ of teachers who responded they never increased students' motivation by promoting learner autonomy.

\section{The Implementation of Motivational Strategies used by English Teachers in Teaching English as a Foreign Language.}

The findings of this research provide evidence that the teachers in each of the six case studies use motivational teaching strategies in their classrooms. What the six teachers reported in the semi-structured interview was mostly captured in the classroom observations. The findings will be discussed in relation to Dörnyei's (2001) MTP framework.

\subsection{Creating Basic Motivational Conditions}

Based on Dörnyei's (2001) framework, when a teacher creates students' motivation, at least there are three components usually presented: appropriate teacher behaviours and a good relationship with students; a pleasant and supportive classroom atmosphere; and a cohesive learner group with appropriate group norms. These three components are interrelated (Dörnyei, 2001). In relation to the first component, Dörnyei draws attention to four important points: teacher enthusiasm; commitment to, and expectations for the students' learning; the teacher relationship with students; and the teacher relationship with students' parents (Dörnyei, 2001). All six teachers showed that they were dedicated to teaching. They were enthusiastic teachers who came to the classroom with a positive manner, for instance, smiling.

All six teachers built warm and firm relationship with their students. They really appreciated their students' ideas and opinions by listening to the students' idea respectfully 
and always paid attention to the students. In line with the studies from Astuti (2013) who stated both inside and outside classroom the teachers always tried to get close with the students so there was no distance from teacher with students. Alshehri (2013) mentioned the main strategies related to teacher behaviour are concerned with building a good relationship with students which needs to be based on caring for the students, that the students like the teacher. This can be done by a willingness to be open, to speak to the students about their issues, to be a role model and to share their own experiences. In this current study, all teachers encouraged students' motivation by smiling and showing happy face and they also built a relaxing and friendly relationship with their students. In addition, teacher 1 showed that teacher built good relationship with the students by trying to remember the students' names and greeted them using their nicknames. By doing this, teacher maintained a friendly and informal relationship with her students. Maintaining a good relationship with their students' parents can help a teacher build a good relationship with students. For most students, parents have a big influence on their learning and play an important part in their learning motivation (Dörnyei, 2001). None of the six teachers mentioned this as part of building students' classroom motivation. The purpose of this relationship is to increase students' achievement in general. Subject teachers did not have direct responsibility for building this relationship.

The second component in creating students' motivation was the provision of a pleasant and supportive classroom atmosphere. Dornyei mentioned that humour is a tool to create a pleasant classroom atmosphere (Dornyei, 2001). In line with study from Alshehri (2013) the need for a pleasant classroom atmosphere and the drawback of having a serious class. Teacher appears to view the process of learning in terms of the outcome which relates to students' progression in the L2 learning. Teacher 1 applied creating a pleasant atmosphere in the classroom by using some humour or jokes in the teaching and learning processes. Teacher 1 also gave motivational advice to the students to increase students' motivation before started the lesson. Next, teachers 2,4, and 5 showed that they created a pleasant atmosphere in the classroom by giving help to her students to speak in English and never got angry if students got incorrect pronunciation. Then, in learning English, the teachers asked the students to express their ideas freely. Even students made mistake in learning, teachers always said that making mistakes in learning process is natural part of learning. All their students felt relaxed in the classroom because the teacher made the learning atmosphere relaxed. However, teachers 3, and 6 did not mention that they created pleasant atmosphere in the learning process.

Dörnyei mentions that humour is a tool that creates a pleasant classroom atmosphere (Dörnyei, 2001). As noted, teacher 1 created an encouraging and relaxed atmosphere by positioning herself as friendly, and she also displayed her own sense of humour. Teacher told jokes, funny stories, life experiences, and gave advice as an icebreaker before starting a lesson. Lamb (2012) also found that classroom learning experiences had an important role in increasing Indonesian students' motivation to learn English. Humour seemed to be an effective way to create a comfortable classroom environment.

Third component of creating students' motivation was the establishment of a cohesive learner group. Study from Alshehri (2013) stated that all the teachers talked about how creating a cohesive class has a positive effect on group work. Teachers also stated that in order to create a cohesive class, using 'group work' is a useful strategy. Similarly, Astuti (2013) asserts that teachers usually managed classes by putting students in pairs or groups. The teachers argued that by doing pair-work or group- work the students would support each other. In addition to this current study all six teachers implemented group-work or pair-work activities in their teaching. Teacher 1 stated that she asked the students to do group work if there was material that required them to work in groups. She usually asked them to make 
video conversations and would ask them to upload the results of their videos to social media like YouTube.

All teachers stated that was important to use group or pair work because in the curriculum of thirteen namely K-13, it was a must to conduct collaborative learning which insists students to work in group or pair and if possible it is indeed those who are looking for the concept. Hence, for individual practice or task, it would be very rare. Next, component in the third component was creating classroom rules in the learning process. This was the basis of classroom management. The teacher and the students should therefore negotiate rules of conduct (Dörnyei, 2001). Dörnyei mentioned that the rules should be easy to follow and explicitly discussed so that members of each group could adopt them. This is also in line with a study from Astuti (2013) that the teachers also highlight the important role of teachers in managing their classrooms. The teachers showed that they were effective in managing their classes by setting up the classroom rules. The same as this current study, all six teachers set up their classroom learning rules with their students. Teacher 1 stated her classroom rules; they were not allowed to be late to come to the English class, students should not laugh at their friends' mistakes, they were not allowed to eat and drink other than mineral water in the class and they had to bring a dictionary. Teacher 1 showed that in the classroom observation one of students in the XI B who ate candy in the classroom last week. She got punished by the teacher to buy candy to her classmates. When the writer did classroom observation, the teacher gave the candies to every student in the class from the student who got the punishment. Teacher 3 stated her classroom rules; all students had to memorize and wrote down 5 vocabulary words every day. Next, for all the teachers asked their students to bring a dictionary. Then, the students had to speak English when they wanted to ask for permission to her teachers such as they wanted go to the toilet. Dörnyei indicates briefly how a teacher must discipline learners who break the rules. He mentions that this is less to do with students' motivation and more a classroom management issue. Teacher 1 stated that dealt with the students who were unmotivated or misbehaved during the learning process was by talking to them personally. If these students remained unmotivated or continued to misbehave, teacher 1 would mostly ignore these students during class and talk to them later.

Teachers implemented the first phase of Dörnyei's framework by showing proper good behaviour to the students, developing personal good relationship with students, creating a pleasant and supportive atmosphere in the classroom, and creating cohesive learner group (e.g. using pair or group work in learning process and setting up classroom learning rules with students). It seems that most teachers who applied this phase in their teaching thought that creating basic motivation was important because the foundation should have been made before they got deeper into the lesson and it could be applied to every student. However, there were strategies from the framework that did not emerge from the data; which is building a relationship with students' parents. None of the six teachers mentioned this as part of building students' classroom motivation.

\subsection{Generating Initial Motivation}

First component of generating students' motivation was introducing the instrumental value of the language. Teacher 1 showed that in the classroom observation, the teacher reminded students the benefit of mastering English in the classroom. Teacher reminded the students that they had to do more practices in their daily life if they want to be able to speak English. In the classroom observation, the skill taught was listening. Therefore, the teacher gave advice to her students that they had to do more practices to listen native speakers who did conversation. The teacher encouraged the learners to apply English language proficiency in real life. Next, teacher 5 stated that she motivated her students to always learn and dare to try 
to use English in their daily lives. For example, people now like to update on social media, so she told them to try to update their status in English so that they were familiar with English. Furthermore, not much different from teacher 5, teacher 2 stated that on Wednesdays there was English Day in the school. Hence, this would be a good way to encourage the students to use English language not only in the English class but also outside the classroom.

From the result above, teachers believed that motivational strategies focused on the instrumental value of the L2 had wide beneficial to relate to students' present time and the future time. However, teachers 3, 4 and 6 did not mention that they promoted students' awareness of the instrumental values. The other component of creating students' motivation was increasing students' expectations of success in learning. The students' expectancy of success was influential factor of students' motivation. There are several things that the teachers can do to increase the students' motivation such as offering assistance, letting students help each other, making the success criteria, and considering and removing potential obstacles to learning (Dörnyei, 2001). Similar to the study of Kassing (2011) that proves some teachers reportedly offered assistance in academic matters or asked questions to check for student-teachers' understanding of the courses. To help the students' learning, in this current study, the teachers 1, 2, 3, 4 and 6 increased students' expectation of success in learning by coming over their students and offered help by asking the students whether they understood the task given and giving students the opportunity to ask questions if they did not understand the task. Then, they also gave more examples when students needed help. They appeared to understand their students' need. They ensured that students received sufficient preparation and assistance. Teachers 3 and 6 helped their students to translate some Indonesian words into English words. This strategy created more positive attitude to language learning. However, only teacher 5 that did not mention she applied this strategy. To make teaching materials relevant to learners, four teachers such as teachers 1,2, 3 and 4 stated that they chose materials and examples that were relevant to a teenager's life by giving the examples based on students' real life, suitable for their English level, and they used simple sentences to explain lessons. These strategies impacted on students' understanding of lessons.

Teacher 1 stated that she conveyed the material in the language style that was understood by students by considering the words selection and lesson and using some media like audio recording. The material was about asking someone planning and telling our planning. Teacher related the material to the real daily life. The teacher gave the example of expression of asking someone planning and telling our planning. Hence, students would be more interested in following the learning process in the classroom. It was important to help students get the main point and benefits of the material learned. In addition, teacher 3 stated that she gave the material to be more interesting by taking it from various sources such as the internet. If it was just from a book, it was not complete and students would be boring. However, there were teachers 5 and 6 who did not apply this strategy in their learning process.

In summary, three out of four strategies given by Dörnyei in this phase emerged in the data. They were; promoting students' awareness of the instrumental values, increasing students' expectations of success in learning and making the curriculum and teaching materials relevant to the students and developing the students' intrinsic interest in the L2 learning process. However, there were four strategies in the framework did not emerge from the finding, namely, promoting the students' language-related values, and promoting integrative (external) values by encouraging a positive and open-minded attitude towards the language learning and creating realistic students' beliefs and goals.

\subsection{Maintaining and Protecting Motivation}

The teachers had strategies to present task in a motivating way. Dornyei (2001) has found 
that the way teachers present a task can make a huge different in how students perceive and approach them. Teachers should present task in a motivational way to maintain students' motivation. They can do this by making tasks interesting for students. In the case stated in current finding, the teachers 1 and 2 stated that in the learning process and when she gave task or practice to students. They gave the task in motivating way by explaining the purpose and utility of a task then she used audio or video aids and usually adopted the task from internet or any sources. In the speaking skill they usually asked them to role play. They emphasized that they did not only focus on textbook but adopted from any other sources. All students enjoyed working on the task given. Different from the teachers 1 and 2, the teacher 3 discussed the way she presented or gave the task in motivating way by making the activities of learning outside the classroom. By making the activities outside the classroom the students could learn directly in the surrounding environment. Teachers 1 and 2 also used specific goals by telling students about the purposes of learning the materials and activities.

Next strategy that the teachers applied in this phase was they had strategies to protect the learner's self-esteem and increased their self- confidence, Teachers 1 and 2 used a similar strategy of not giving direct correction when students made errors in speaking in English or when students could not answer the correct teachers' question. They identified the important mistakes and explained them at the end of the session. From the classroom observation, the writer found that teacher 1 did not do direct corrections if teacher found the students made mistake or answer wrongly in the learning process but teacher collected all students' answer and discussed together about the appropriate answers. All teachers viewed mistakes as a natural aspect of learning a language. This is also one of the strategies to allow learners to maintain a positive social image about their learning (Dörnyei, 2001). The way teachers increased students' confidence was reporting by teacher 1 . Teacher 1 gave the task to be done individually then discussed it together. Teacher 1 asked students to come to the class to write their own answer on the whiteboard. The students conveyed opinions freely without fear of making mistakes. Teacher 1 gave appreciation to students. Teacher 3 also reported that teacher used activity that made the students confident to speak in English. The strategy that the teacher applied was the students would take turns throwing rolled of paper. To students who caught the paper, then they would be given the opportunity to answer questions using English. It could encourage them to confidently convey their answers or opinions.

In summary, four out of six strategies given by Dörnyei in this phase appeared in the data. They were making learning stimulating and enjoyable, presenting task in a motivating way and increasing students' confidence. The two strategies that did not appear were increasing students' motivation by promoting students' autonomy and increasing the students' self-motivating capacity. This suggests that the teachers, in these cases, did not encourage self-regulation.

\subsection{Encouraging Positive Self-evaluation}

The teacher can help learners consider their learning achievement positively, helping them to be more satisfied with their success and progress, giving positive feedback that promotes ongoing learning, and giving rewards and grades during class (Dörnyei, 2001). It is in line with the studies of Kassing (2011) who asserted that students were less hesitant in attempting to answer the lecturers' verbal questions or performing assigned tasks when they knew that lecturers appreciated their effort, or at least would not embarrass them either verbally or nonverbally in front of the class. The data obtained in this current research indicated thatthe teachers encouraged the students to be more satisfied with their success and progress. Teacher 1 said her main target was not only about the grade but their skill or their effort. Yet, it can be seen during the daily learning process in the classroom. Therefore, teacher 1 had to know in advance the students' process of learning. When there were students who got poor results but knew that their learning process in the classroom was good, it could be considered. 
It was not only the final grades that took precedence but during their processes or efforts when learning in classroom. However, it should be noted that the teacher 1 respected students even if they were weak compared to their classmates. The other strategy that teacher 1 applied was during the teaching learning process, teacher 1 usually make notes regarding the common errors or after checking the students' work then discussed the common mistakes with the class. Similar study from Alshehri (2013) showed EFL lecturers in her explanation that they usually made notes regarding the common errors during the teaching-learning process. In addition, teacher1 mentioned that teacher tried to provide motivational feedback by giving positive feedback such as giving compliment to students and teacher also appreciated student's work. Similarly, the study from Astuti (2013) shows that all teachers complimented their students on their performance rather than criticized them. Furthermore, teacher 1 also offered rewards and grades to her students. As teacher, teacher saw assessment as part of their role and teacher also evaluated their students from the learning process, not just from the semester test. Different from teacher 1, the other teachers reported that they did not offer rewards to their students. They only used grade and point as their way to encourage positive students' evaluation.

\section{CONCLUSION}

This research has qualitatively explored the English teachers in secondary Islamic school in Tangerang. The findings clearly showed the motivational strategies used by English teachers in teaching English as a foreign language. The focus question of the study is the motivational strategies used by English teachers in teaching EFL in secondary Islamic school in Tangerang. The sub-focus questions of the study are the frequency of motivational strategies used by English teachers in teaching EFL in secondary Islamic school in Tangerang and the implementation of motivational strategies that the English teachers used in in teaching EFL in secondary Islamic school in Tangerang.

This study aimed to find motivational strategies used by English teachers and analyzed it based on four motivational phases as proposed by Dornyei (2001). The finding of this study indicated that the English teachers in secondary Islamic school in Tangerang were good in implementing the motivational strategies in their teaching process. It illustrated that the participants implement the phases of motivational strategies by creating basic motivational condition, generating initial motivation, maintaining and protecting motivation and encouraging positive self-evaluation.

Those phases mostly used by the English teachers in secondary Islamic school in Tangerang. Creating basic motivational condition were divided into showed good behaviour to the students, developed personal good relationship with students, created pleasant and supportive atmosphere in the classroom and created cohesive learner group. Generating initial motivation divided into promoted students' awareness of the instrumental values, increased students' expectations of success in learning and made the curriculum and teaching materials relevant to the students. Maintaining and protecting motivation divided into made learning stimulating and enjoyable, gave task in a motivating way and increased students' confidence and encouraging positive self-evaluation divided into gave feedback positively to their students and offered rewards and grade in a motivating way.

Furthermore, from the sample that emerged in the findings. The English teachers in secondary Islamic schools in Tangerang were good in implementing motivational strategies to enhance students' motivation. Teachers considered four phases of motivational strategies proposed by Dornyei (2001) were important to be implemented by the English teachers in their teaching and learning process. Even though there were only a few teachers who did not apply phases of motivational strategies completely. 


\section{REFERENCES}

Alshehri, E. A. (2013). Motivational Strategies: The perceptions of EFL Teachers and Students in The Saudi Higher Education Context. International Journal of English Language Education, 5(2), 46-82.

Astuti, S. P. (2013). Teachers' and students' perceptions of motivational teaching strategies in an Indonesian high school context. TEFLIN Journal, 24(1), 1-18.

Baranek, L. K (1996). The Effect of Rewards and motivation on Student Achievement. Unpublished master's thesis, GrandValley State University, Allendale, Michigan, United states. Retrieved January 19, 2019, from http://scholarworks.gvsu.edu/cgi/viewcontent.cgi?srticle=1292\&context=t heses

Bradford, A. (2007). Motivational orientations in under-researched FLL context: Findings from Indonesia. RELC Journal, 38(3), 302-323. https://doi.org/10.1177/0033688207085849

Cowie, N., \& Sakui, k. (2011). Crucial but Neglected: English as a foreign Language Teachers ${ }^{\text {ee }}$ Perspectives on Learner Motivation. Murray, G., Gao, X.A., \&Lamb, T. (Eds.). (2011). Identity, motivation and autonomy in language learning (pp.212-227). United Kingdom: Multilingual Matters.

Dornyei, Z. (2001). Motivational strategies in language classroom. Cambridge: Cambridge University Press.

Dornyei, Z., \& Ushioda, E. (2011). Teaching and researching motivation (2nd ed.). Harlow: Pearson Education Limited.

Guilloteaux, M. J., \& Zoltan, D. (2008). Motivating Language Learners: A Classroom Oriented Investigation of Student Motivation. TESOL Quarterly, 42(1), 55-77.

Kakar, S. K., \& Pathan, Z. H. (2017). Exploring the motivational strategies practiced by Pakistani EFL teachers to motivate students in learning English language. International Journal of English Linguistics, 7(2), 117.

Kassing, R. B. (2011). Perception of motivational teaching strategies in an EFL classroom: The case of a class in private university in Indonesia. (Master Thesis, Victoria University of Wellington, Wellington, New Zealand). Retrieved from http://researcharchieve.vuw.ac.nz/bitstream/handle/10063/1835/thesis.pdf? sequence=2 .

Lamb, M (2007). The impact of school on EFL learning motivation: An Indonesia case study. TESOL quarterly, 41 (4), 757-780. https://doi.org/10.1002/j.1545-7249.2007.tb00102.x

Liando, N. V. F., Moni, K. B., \& Baldauf, J. R. B. (2005). Student motivation in learning English as a foreign language in an Indonesian context. In J. Yamanashi \& I. Milojevic (Eds.), Researching Identity, Diversity \& Education: Surpassing the Norm (pp. 168179). Tenerife: Post Pressed.

Maeng, U., \& Lee, S. M. (2015). EFL teachers' behaviour of using motivational strategies: 
The case of teaching in the Korean context. Teaching and Teacher Education, 46, 2536. https://doi.org/10.1016/j.tate.2014.10.010

Moskovsky, C., \& Alrabai, F. (2009). Intrinsic motivation in Saudi learners of English as a foreign language. The Open Applied Linguistics Journal, 2(1).

Murray, G., Gao, X.A., \& Lamb, T. (Eds.). (2011). Identity, motivation and autonomy in language learning. United Kingdom: Multilingual Matters. Retrieved July 8, 2019, from http://en.bookfi.net/book/1404867

Nunan, D., \& Bailey, K. M. (2009). Exploring second language classroom research: A comprehensive guide. Australia: Heinle Cengage Learning.

Park, C.C. (2000). Learning style preferences of Southeast Asian Students. Urban Education, 33(3), 254-268. https://doi.org/10.1177/0042085900353002

Sucuoglu, E. (2017). Analysis of motivational strategies used by English language teachers teaching at secondary schools. Procedia Computer Science, 120, 189-195. https://doi.org/10.1016/j.procs.2017.11.228

Sugita, M., \& Takeuchi, O. (2010). What can teachers do to motivate their students? A classroom research on motivational strategy use in the Japanese EFL context. Innovation in Language Learning and Teaching, 4(1), 21-35.

Temple, B., \& Young, A. (2004). Qualitative research and translation dilemmas. Qualitative research, 4(2), 161-178.

Penny, U. (1996). A course in language teaching: Practice and theory. Cambridge: Cambridge University. 